\title{
Assessment the Prevalence of Pulmonary Tuberculosis Patients at Yirga Cheffe Health Center from 2008-2013, Ethiopia
}

\author{
Fekadu Alemu Atire \\ Department of Biology, College of Natural and Computational Sciences, Dilla University, Dilla, Ethiopia
}

Email address:

fekealex@gmail.com

To cite this article:

Fekadu Alemu Atire. Assessment the Prevalence of Pulmonary Tuberculosis Patients at Yirga Cheffe Health Center from 2008-2013, Ethiopia. Clinical Medicine Research. Vol. 4, No. 2, 2015, pp. 38-42. doi: 10.11648/j.cmr.20150402.13

\begin{abstract}
Mycobacterium tuberculosis, the causative agent of tuberculosis (TB), is one of the world's most devastating human pathogens that cause more than 2 million deaths annually. In addition, an estimated 2 billion people are latently infected with M. tuberculosis. Ethiopia is ranked $7^{\text {th }}$ among TB burden shouldering countries in the world. The data collection was carried out typically by secondary data source from already recorded document. The data was obtained from the data clack of pulmonary tuberculosis patients (PTB) individuals at Yirga Cheffe Health Center. From a total of 1190 subjects who are registered to assessed for tuberculosis diseases at the Yirga Cheffe Health Center study sites, 676 (56.81\%) male were diagnosed followed by female 514 (43.19 \%) were diseased by Mycobacterium tuberculosis. The PTB disease were highly predominant among male with increase slightly across the year from 2008-2013 and the highest were $58.75 \%$ at 2013 . The TB disease were increased among children from 2008-2013 in both sex (male and female). The highest percentage of pulmonary tuberculosis patients were observed at 2012 on male at age $>49$ with $10.18 \%$ while on female pulmonary tuberculosis patients were observed at 2011 with $7.32 \%$. To conclude that the prevalence of PTB disease among both sex at study area were high in early. The pulmonary tuberculosis patients were decreased across the 2008-2013.
\end{abstract}

Keywords: Ethiopia, Mycobacterium tuberculosis, Pulmonary Tuberculosis Patients, TB, Yirga Cheffe Health Center

\section{Introduction}

Tuberculosis (TB) is one of the leading infectious disease and health burden in the world (Dye et al., 1999). TB is a bacterial disease caused by Mycobacterium tuberculosis (and occasionally by Mycobacterium bovis and Mycobacterium africanum). The causative organism of tuberculosis, the tubercle bacillus, was isolated and described by Robert Koch in 1882. It is a fastidious, slow growing, lipid-rich, hydrophobic and acid fast bacterial rod shape which resists decolorization with acid alcohol. Tuberculosis is a mycobacterial infection that affects a wide range of mammals. Transmission occurs by airborne spread of infectious droplets. The source of infection is a person with TB of the lung who is coughing. Coughing produces tiny infectious droplets (droplet nuclei). One cough can produce 3,000 droplet nuclei. M. tuberculosis infects a third of the world's population. Human and bovine tuberculosis (TB and BTB respectively) share key aspects such as developing similar lesions and immune responses, which often result in colonization and spread to the same organs, namely lungs and lymphatic tissues (Buddle et al., 2005; Cassidy, 2006; O'Reilly and Daborn, 1995; Van Rhijn et al., 2008). Bovine tuberculosis (BTB) is a chronic, granulomatous mycobacterial infectious disease caused mainly by Mycobacterium bovis, which is a member of Mycobacterium tuberculosis complex (MTC) Ayele et al., 2004; OIE, 2010).

Every year approximately 9 million people contract tuberculosis (TB) and close to 2 million die from the disease (World Health Organization, 2005). The most TB cases are in Asia, the highest incidence rates are in Africa where high rates of HIV and malnutrition weaken immune systems and accelerate the spread of the disease (World Health Organization, 2009). Consequently, the number of new TB cases in most African countries has more than quadrupled since 1990, with 2.8 million new TB cases and roughly 735 thousand deaths annually (World Health Organization, 2005). Worldwide in 1995 there were about 9 million new cases of TB with 3 million deaths. These deaths comprise $25 \%$ of all avoidable deaths in developing countries. $95 \%$ of TB cases 
and $98 \%$ of TB deaths are in developing countries. $75 \%$ of TB cases in developing countries are in the economically productive age group (15-50 years).

Pulmonary TB features (Cough, fever, sweats, weight loss and haemoptysis) and extra-pulmonary lymphnode swelling (lymphadenitis) are leads that used in identifying diseases symptomatically. Apart from lung and lymphnode the disease can occur in any part of the body, including the meninges, bone and kidneys that land marks disseminated/miliary TB (Fitzgerald and Haas, 2005). In developing countries, animal TB is widely distributed where control measures are not applied or are applied sporadically (Cosivi et al., 1998). Mycobacterium bovis was isolated in numerous African countries from abattoir lesions and clinically suspected bovines and there seem to be an endemic state of bovine tuberculosis in some of these nations (Rigouts et al., 1996; Sulieman and Hamid, 2002; Oloya et al., 2007).

Drug resistance tuberculosis threatens the National Tuberculosis Control Programme in several countries, and the major problem is multidrug resistance TB (MDR-TB) (WHO/IUATLD, 2000). MDR-TB is defined as M. tuberculosis strains that are resistant to at least isoniazid and rifampicin, the two key first line drugs in short course TBchemotherapy. Resistance to any single TB drug is close to $10 \%$ in all African countries surveyed (Aziz et al., 2006). The problem of drug resistant TB exists in different parts of Ethiopia, and data on patterns of resistance among Ethiopian isolates is ranging from $2 \%-21 \%$ for isoniazid, $2 \%-20 \%$ for streptomycin and $14 \%-15 \%$ for any of the drugs tested (Demissie et al., 1997; Abate, 2002; Bruchfeld et al., 2002). MDR-TB was also reported in about $1.2 \%$ of new cases and $12 \%$ of re-treatment cases (Abate, 2002). Little information is available in Ethiopia related to drug susceptibility assay on M. tuberculosis isolates from smear negative and culture positive sputum samples (Ejigu et al., 2008).

In Ethiopia, the incidence of TB is estimated at 359 new cases per 100,000 populations and the country is rated $7^{\text {th }}$ among the 22 high burden countries (WHO, 2011). The situation is exacerbated by HIV co-infection, with approximately $20 \%$ of cases presenting with TB also coinfected with HIV (WHO, 2011). In Ethiopia, based on the detection of tuberculous lesions, condemnation of carcasses totally or partially is a standard practice for the control of zoonotic tuberculosis infections at abattoirs. Detection of tuberculous lesions in slaughterhouses takes place by observation of the visible tuberculous lesions in infected cattle; however, the level of the quality of such practices may vary from place to place and/or abattoir to abattoir in the country. Among the undertaken abattoir studies, prevalence rate ranges from 3.5 to $5.8 \%$ (Ameni and Wudie, 2003; Teklul et al., 2004; Shitaye et al., 2006; Romha et al., 2013) have been reported in different abattoirs in the country.

The eastern part of Ethiopia is known for its high TB case load and anti-TB drugs have been in use for long time in the area before the implementation of directly observed treatment short course (Mitike et al., 1997). However, there is a paucity of data on prevalence in this part of the country. Therefore, this study was conducted to assess the prevalence of tuberculosis disease among pulmonary tuberculosis patients (PTB) at Yirga Cheffe Health Center in SNNPR, Ethiopia.

\section{Materials and Methods}

\subsection{Study Area}

The study was conducted at Yirga Cheffe Health Center in Dilla town surrounding, south of Addis Ababa and far from Addis Ababa was $395 \mathrm{~km}$, in Gedeo zone, SNNPR. Study was conducted from March 2013 to June 2014 at Yirga Cheffe Health Center, South of Addis Ababa, Ethiopia.

\subsection{Data Collection Technique}

The data collection was carried out typically by secondary data source from already recorded document. The data was obtained from the data clack of pulmonary tuberculosis patients (PTB) individuals at Yirga Cheffe Health Center.

\subsection{Data Analysis}

Data were checked for completeness, cleaned manually and entered and analyzed using SPSS version 16 statistical package. Data were summarized using frequency tabular and graphical expression form through percentage.

\subsection{Ethical Consideration}

Ethical clearance was obtained from Dilla University, College of Natural and Computational Sciences, Department of Biology.

Table 1. The prevalence of PTB patients at Yirga Cheffe Health Center from 2008-2014, Ethiopia

\begin{tabular}{|c|c|c|c|c|c|}
\hline \multirow{2}{*}{ Year } & \multirow{2}{*}{ Sex } & \multicolumn{3}{|l|}{ Age } & \multirow{2}{*}{ Number of patients registered } \\
\hline & & Children (0-14) & Young (15-49) & Old $(>49)$ & \\
\hline \multirow{3}{*}{2008} & Male & $7(3.14 \%)$ & $106(47.53 \%)$ & $16(7.17 \%)$ & $129(57.85 \%)$ \\
\hline & Female & $3(1.35 \%)$ & $82(36.77 \%)$ & $9(4.04 \%)$ & $94(42.15 \%)$ \\
\hline & Total & $10(4.49 \%)$ & $188(84.30 \%)$ & $25(11.21 \%)$ & $223(100.00 \%)$ \\
\hline \multirow{3}{*}{2009} & Male & $4(1.83 \%)$ & $105(47.95 \%)$ & $15(6.85 \%)$ & $124(56.63 \%)$ \\
\hline & Female & $3(1.36 \%)$ & $84(38.36 \%)$ & $8(3.65 \%)$ & $95(43.37 \%)$ \\
\hline & Total & $7(3.19 \%)$ & $189(86.31 \%)$ & $23(10.50 \%)$ & $219(100.00 \%)$ \\
\hline \multirow{3}{*}{2010} & Male & $5(2.31 \%)$ & $99(45.84 \%)$ & $17(7.87 \%)$ & $121(56.01 \%)$ \\
\hline & Female & $3(1.39 \%)$ & $82(37.96 \%)$ & $10(4.63 \%)$ & $95(43.98 \%)$ \\
\hline & Total & $8(3.70 \%)$ & $181(83.80 \%)$ & $27(12.50 \%)$ & $216(100.00 \%)$ \\
\hline
\end{tabular}




\begin{tabular}{llllll}
\hline \multirow{2}{*}{ Year } & \multirow{2}{*}{ Sex } & Age & & & Number of patients registered \\
\cline { 3 - 5 } & Children (0-14) & Young (15-49) & Old (>49) & $115(56.10 \%)$ \\
\multirow{2}{*}{2011} & Male & $7(3.41 \%)$ & $93(45.37 \%)$ & $15(7.32 \%)$ & $90(43.90 \%)$ \\
& Female & $4(1.95 \%)$ & $73(35.61 \%)$ & $13(6.34 \%)$ & $205(100.00 \%)$ \\
& Total & $11(5.36 \%)$ & $166(80.98)$ & $28(13.66 \%)$ & $93(55.69 \%)$ \\
2012 & Male & $4(2.40 \%)$ & $72(43.11 \%)$ & $17(10.18 \%)$ & $74(44.31 \%)$ \\
& Female & $4(2.40 \%)$ & $65(38.92 \%)$ & $5(2.99 \%)$ & $167(100.00 \%)$ \\
& Total & $8(4.80 \%)$ & $137(82.03)$ & $22(13.17 \%)$ & $94(58.75 \%)$ \\
& Male & $9(5.63 \%)$ & $74(46.25 \%)$ & $11(6.87 \%)$ & $66(41.25 \%)$ \\
& Female & $7(4.37 \%)$ & $54(33.75 \%)$ & $5(3.13 \%)$ & $160(100.00 \%)$ \\
\hline
\end{tabular}

\section{Results and Discussion}

From a total of 1190 subjects who are registered to assessed for tuberculosis diseases at the Yirga Cheffe Health Center study sites, $676(56.81 \%)$ males were diagnosed followed by females $514(43.19 \%)$ were diseased by Mycobacterium tuberculosis. Of the 223 PTB patients were $57.85 \%$ males followed by females $42.15 \%$. In addition to this the young age classes were highly affected by PTB $(84.30 \%)$ from other age class in 2008 as indicted in the Table 1. The PTB were highly prevalent among Young age (15-49) than other age class like children and old in all study year 2008-2013 and also higher on males than females. Beside of this, in all study year the males were highly infected by Mycobacterium tuberculosis than the female age classes as shown in Table 1. As reported by Assam-Assam et al. (2011) that from a total of 756 subjects who presented clinical symptoms of tuberculosis at the hospital study sites, $154(20.37 \%)$ were diagnosed positive by smear microscopy. They were 100 men (64.93\%) and 54 women (35.07\%). Patients' age distribution showed a steady decline in agespecific prevalence from $30.58 \%$ in age group $15-29$ years to $15.51 \%$ in the age group above 60 years. Of the 154 patients, $32(20.77 \%)$ were HIV positive; while 135 (87.66\%) were new cases and $19(12.33 \%)$ were old cases.

\subsection{Prevalence of PTB Disease Among both Sex Male and Female from 2008-2013 at Yirga Cheffe Health Center, Ethiopia}

The PTB diseases were highly predominant among males with increase slightly across the year from 2008-2013 and the highest were $58.75 \%$ at 2013. The highest PTB diseases $44.31 \%$ were observed at 2012. The percentage of PTB patients among females were slightly decreased from 20082013 as indicated in figure 1 . The majority of the patients were men $(63.93 \%)$ and this was found to be in agreement with previous findings (Godfrey-Faussett et al., 2000). Tuberculosis is the most frequent cause of death from a single infectious disease in persons aged 15-49 years. About 8.4 million people develop active tuberculosis every year and 2.3 million die of it. It is estimated that 200 million additional people are at risk of developing the disease in the next 20 years, if the current trends are conserved (Miller and Schieffelbein, 1998).

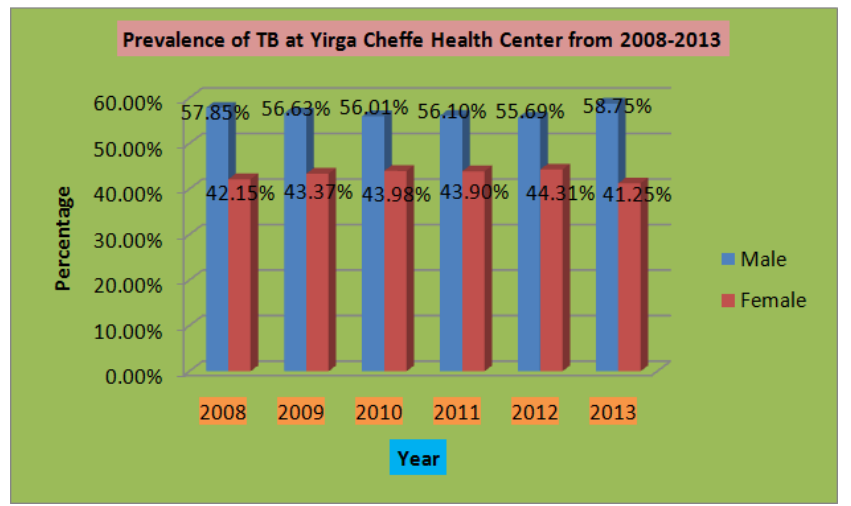

Figure 1. The prevalence of PTB disease among both sex male and female from 2008-2013 at Yirga Cheffe Health Center.

\subsection{Prevalence of PTB Disease Among Children Age (0-14) at Yirga Cheffe Health Center from 2008-2013, Ethiopia}

The highest number of PTB patients of males diagnosed was observed among children at 2013 with percentage of $5.63 \%$ and followed $3.41 \%$ at 2011 . The TB diseases were increased among children from 2008-2013 in both sex (male and female). The highest number of PTB patients of female was observed at 2013 with $4.37 \%$ as shown the figure 2 . As report presented at the $10^{\text {th }}$ annual review meeting Tuberculosis and Leprosy Control Programmed (TLCP) Ethiopia (18 to 20 September 2002) showed that the incidence of tuberculosis was the increase (TLCP, 2002).

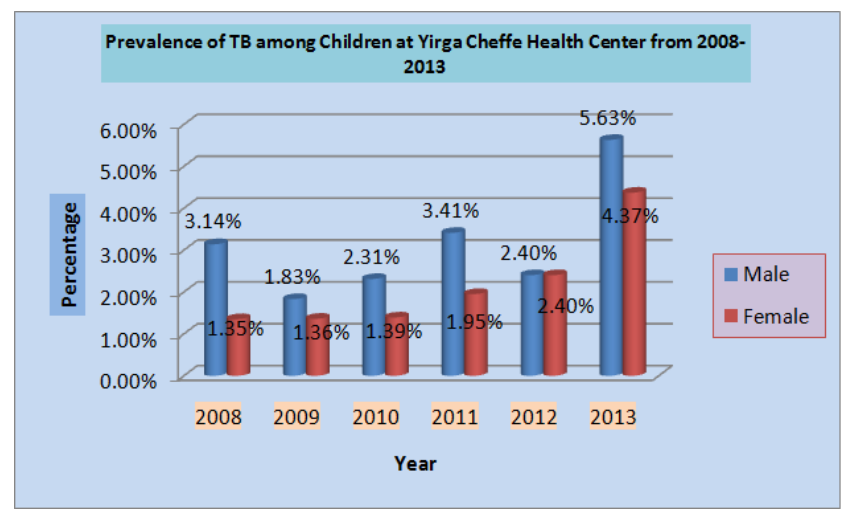

Figure 2. The prevalence of PTB disease among children age (0-14) at Yirga Cheffe Health Center from 2008-2013. 


\subsection{Prevalence of PTB Disease Among Young (15-49) Age at Yirga Cheffe Health Center from 2008-2013, Ethiopia}

The highest percentage of PTB patients among males were $47.53 \%$ in addition, the percentage of PTB patients males were relatively high than female across the year from 20082013. The percentage of both males and females PTB patients were slightly decreased from 2008-2013. Moreover, the highest percentage of PTB patients of females were observed at 2012 with $38.92 \%$ as indicted in the figure 3 . The burden of TB in Ethiopia is one of the highest in the world and based on estimated number of cases the country is placed to rank $10^{\text {th }}$ among the 22 high burden countries (HBC) (WHO, 2003).

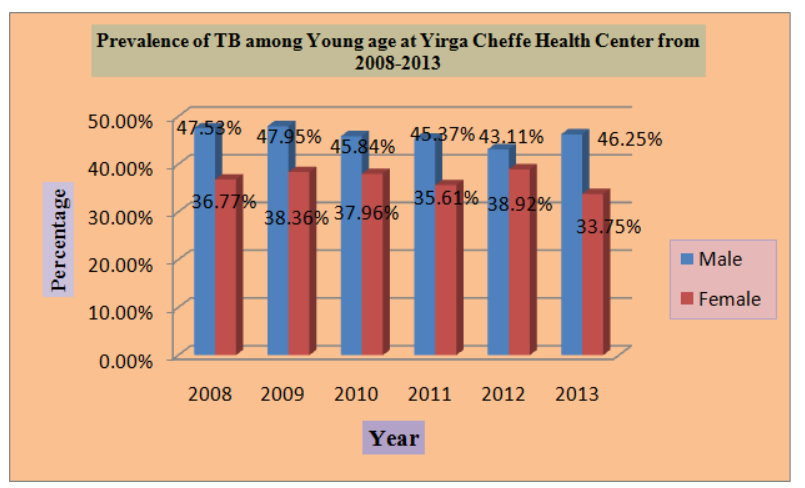

Figure 3. The prevalence of PTB disease among Young (15-49) age at Yirga Cheffe Health Center from 2008-2013.

\subsection{Prevalence of PTB Disease Among Old Age $>49$ at Yirga Cheffe Health Center from 2008-2013, Ethiopia}

The highest percentage of PTB patients were observed at 2012 on male with $10.18 \%$ while on females PTB patients were observed at 2011 with $7.32 \%$. The prevalence of PTB disease among females were slightly decreased across the year from 2008-2013 except at 2012. In addition the percentage of PTB disease among the males across the year were decreases from 2008-2013 except at 2012 as indicted in figure 4. In most developing countries two third of the reported TB patients are men (WHO, 1998). Comparable results have been reported from Ghana (Hudelson, 1996).

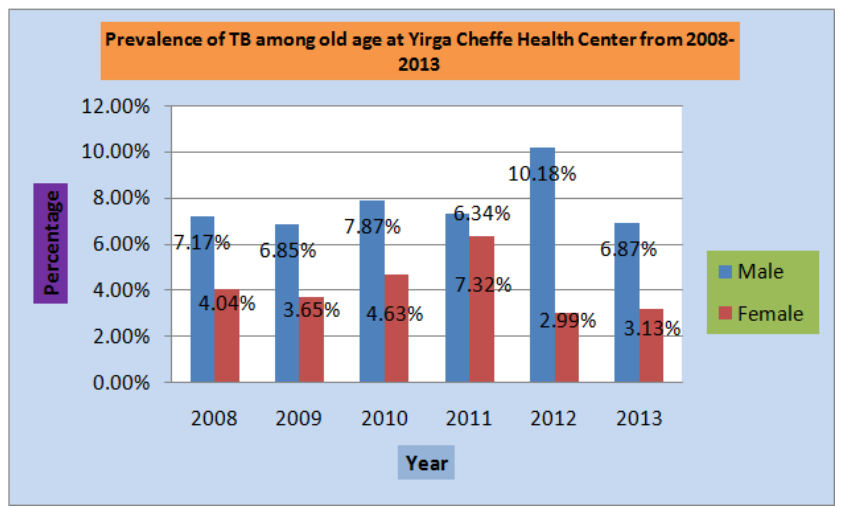

Figure 4. The prevalence of PTB disease among Old age $>49$ at Yirga Cheffe Health Center from 2008-2013.

\section{Conclusion}

The study revealed that the prevalence of PTB disease among both sex at study area were high in early. However, currently the distribution PTB disease among both males and females were slightly decrease across the year from 2008-2013.

\section{Acknowledgments}

The authors would like to acknowledge the Dilla University for providing the facilities and some transportation.

\section{References}

[1] Abate G (2002). Review: Drug resistance tuberculosis in Ethiopia Problem scenarios and recommendation. Ethiop. Med. J. 40:79-86.

[2] Ameni G, Wudie A (2003). Preliminary study on bovine tuberculosis in Nazareth municipality abattoir of central Ethiopia. Bulletin of Animal Health and Production in Africa 51: $125-132$.

[3] Assam-Assam J - P, Penlap V B, Cho-Ngwa F, Tedom J-C, Ane-Anyangwe I, Titanji, V P (2011). Mycobacterium tuberculosis complex drug resistance pattern and identification of species causing tuberculosis in the West and Centre regions of Cameroon. BMC Infectious Diseases 11:94.

[4] Ayele W, Neill S, Zinsstag J, Weiss M, Pavlik I (2004). Bovine tuberculosis: an old disease but a new threat to Africa. International Journal of Tuberculosis and Lung Diseases 8: 924-937.

[5] Aziz MA, Wright A, Laszlo A, De Muynck A, Portaels F, Van Deun A, Wells C, Nunn P, Blanc L, Raviglione M (2006). Epidemiology of antituberculosis drug resistance (the Global Projecton Anti-tuberculosis Drug Resistance Surveillance): an updated analysis. Lancet 368:2142-2154.

[6] Bruchfeld J, Aderaye G, Berggren Palme I, Bjorvatan B, Gebremichael S, Lindquist L (2002). Molecular epidemiology and drug resistance of Mycobacterium tuberculosis isolates from Ethiopian pulmonary TB patients with and without HIV infection. J. Clin. Microbiol. 40:1636-43.

[7] Buddle B M, Skinner M A, Wedlock D N, deLisle G W, Vordermeier H M, Hewinson R G, (2005). Cattle as a model for development of vaccines against human tuberculosis. Tuberculosis 85: 19-24.

[8] Cassidy J P (2006). The pathogenesis and pathology of bovine tuberculosis with insights from studies of tuberculosis in humans and laboratory animal models. Veterinary Microbiology 112: 151-161.

[9] Cosivi O, Grange J M, Daborn C J, Raviglione M C, Fujikura T, Cousins D, Robinson R A, Huchzermeyer H F de Kantor I, and Meslin F X (1998). Zoonotic tuberculosis due to Mycobacterium bovis in developing countries. Emerging Infectious Diseases 4(1): 59-70.

[10] Demissie M, Gebeyehu M, Berhane Y (1997). Primary resistance to anti-tuberculosis drugs in Addis Ababa, Ethiopia. Int. J. Tuberc Lung Dis. 1:64-67. 
[11] Dye C, Scheele S, Dolin P, PathaniaV, Raviglione MC (1999). Global burden of Tuberculosis: estimated Incidence, prevalence, and mortality by country. JAMA $282: 677-86$.

[12] Ejigu GS, Woldeamanuel Y, Shah NS, Gebeyehu M, Selassie A, Lemma E (2008). Microscopic observation drug susceptibility assay provides rapid and reliable identification of MDR-TB. Int. J. Tuberc Lung Dis.12:332-337.

[13] Fitzgerald D, Haas DW (2005). Mycobacterium tuberculosis. In: Mandell GL, Bennett JE, Dolin R, eds. Mandell, Douglas, and Bennett's Principles and practice of infectious diseases. $6^{\text {th }}$ ed. Philadelphia: Elsevier Churchill Livingstone.

[14] Godfrey-Faussett P, Sonnenberg P, Shearer SC, Bruce MC, Mee C, Morris L (2000). Tuberculosis control and molecular epidemiology in a South African gold- mining community. Lancet 356:1066-1071.

[15] Hudelson P, (1996). Gender differentials in tuberculosis: the role of socio- economic and cultural factors. Tubercle and Lung Disease 77: 391-400.

[16] Miller B, Schieffelbein C (1998). Tuberculosis. Bull World Health Organ .76:141-143.

[17] Mitike G, Kebede D, Yeneneh H (1997). Prevalence of antituberculosis drug resistance in Harar Tuberculosis Centre, Ethiopia,. East African Medical Journal 74: (3)158-161.

[18] O'Reilly L M, Daborn C J (1995). The epidemiology of Mycobacterium bovis infections in animals and man: a review. Tuberculosis and Lung Disease 76: 1-46.

[19] OIE (2010). Bovine tuberculosis. In: Manual of Diagnostic Tests and Vaccines for Terrestrial Animals. Part 2, Section 2.4. World Organization for Animal Health, pp: 683-698.

[20] Oloya J, Muma J B, Opuda-Asibo J, Djonne B, Kazwala R, Skjerve E (2007). Risk factors for herd-level bovine seropositivity in transhumant cattle in Uganda. Prev. Vet. Med. 80 (4): 318-329.

[21] Rigouts L, Maregeya B, Traore H, Collart J P, Fissette K, Portaels F (1996). Use of DNA restriction fragment typing in the differentiation of Mycobacterium tuberculosis complex isolates from animals and humans in Burundi. Tuberculosis and Lung Disease 77: 264-268.

[22] Romha G, Ameni G, Berhe G, Mamo G (2013). Epidemiology of mycobacterial infections in cattle in two districts of Western Tigray Zone, northern Ethiopia. African Journal of Microbiology Research 7(31): 4031-4038.
[23] Shitaye J E, Getahun B, Alemayehu T, Skoric M Treml F, Fictum P, Vrbas V, Pavlik I (2006). A prevalence study of bovine tuberculosis by using abattoir meat inspection and tuberculin skin testing data, histopathological and IS6110 PCR examination of tissues with tuberculous lesions in cattle in Ethiopia. Veterinarni Medicina 11: 512-522.

[24] Sulieman M S, Hamid M E (2002). Identification of Acid Fast Bacteria from Caseous Lesions in Cattle in Sudan. Journal of Veterinary Medicine 49: 415-418.

[25] Teklul A, Asseged B, Yimer E, Gebeyehu M, Woldesenbet Z (2004). Tuberculous lesions not detected by routine abattoir inspection: The experience of the Hosanna municipal abattoir, Southern Ethiopia. Revue Scientifique Technique 23: 957-964.

[26] TLCP (2002).Tenth annual review meeting, Tuberculosis and Leprosy control Programme (TLCP) Ethiopia, 18 to 20 September 2002.Addis Ababa.

[27] Van Rhijn I, Godfroid J, Michel A, Rutten V (2008). Bovine tuberculosis as a model for human tuberculosis: advantages over small animal models. Microbes Infect. 10: 710-715.

[28] WHO (1998). Global tuberculosis control. WHO/ TB/98. 237. Geneva.

[29] WHO (2003). Global tuberculosis control: Surveillance, Planning, Financing. WHO report 2003. Geneva, Switzerland, $\mathrm{WHO} / \mathrm{CDS} / \mathrm{TB} / 2003.316$

[30] WHO (World Health Organization) (2005). Global tuberculosis control: surveillance, planning, financial. WHO report 2005 Geneva, Switzerland.

[31] WHO (World Health Organization) (2005). Tuberculosis Control: The Situation in the African Region. The 55th session of the WHO original committee for Africa held in Maputo, Mozambique, August 2005, resolution AFR/RC55/R5 Geneva, Switzerland.

[32] WHO (World Health Organization) (2009). Global tuberculosis control: epidemiology, strategy, financing. Geneva, Switzerland.

[33] WHO/IUATLD (2000). Anti-tuberculosis drug resistance in the world: the WHO/IUATLD Global Project on Antituberculosis Dug Resistance Surveillance. Report 2: Prevalence and Trends. World Health Organization, Geneva, $\mathrm{WHO} / \mathrm{CDS} / \mathrm{TB}$.

[34] World Health Organization (2011). G. Global Tuberculosis Control WHO Report.

[35] Zeru F, Romha G, Ameni G (2013). Gross and Molecular Characterization of Mycobacterium tuberculosis Complex in Mekelle Town Municipal Abattoir, Northern Ethiopia. Global Veterinaria 11 (5): 541-546. 